УДК 616.71-003.93-092.9:615.849.11

\title{
M.В. Исаев
}

Кафедра хирургии № 1 (зав. - проф. В.В. Бойко)

Харьковского начионального медиииского университета

\section{ВЛИЯНИЕ КВЧ ОБЛУЧЕНИЯ НА РЕПАРАЦИЮ КОСТНОЙ ТКАНИ В ЭКСПЕРИМЕНТЕ}

\begin{abstract}
ВПЛИВ ВВЧ ОПРОМІНЕННЯ НА РЕПАРАЦЮЮ КІСТКОВОЇ ТКАНИНИ В ЕКСПЕРИМЕНТІ Резюме. У роботі наведено експериментальне обгрунтування застосування ВВЧ опромінення в ранньому післятравматичному періоді при модельованій тупій травмі грудної клітки з порушенням цілісності ребрового каркасу. Застосування електромагнітних хвиль міліметрового діапазону дозволяє знизити вираженість запального процесу, прискорити темпи формування кісткового мозоля і сприяє формуванню щільного регенерату в ранні терміни спостереження.

Ключові слова: тупа травма грудної клітки, переломи ребер, ВВЧ опромінення, експеримент.
\end{abstract}

До настоящего времени летальность при торакальной травме остается высокой и составляет $17 \%$ в случаях изолированной и $76 \%$ - множественной и сочетанной [1]. Причинами неблагоприятных исходов травм грудной клетки является развитие посттравматических осложнений (ранних - посттравматических пневмоний, плевритов, эмпиемы и пр. и поздние - остеомиелиты, хронические абсцессы, хроническая эмпиема и пр.). Вопросам профилактики и лечения этих осложнений в литературе уделяется недостаточное внимание [2].

В настоящее время одним из приоритетных направлений является изучение возможностей использования в медицинской практике - хирургии и травматологии, все более коротких волновых диапазонов электромагнитных волн - в частности, волн КВЧ-диапазона [3, 4].

Цель исследования: определение особенностей репаративного остеогенеза ребер у травмированных крыс под воздействием КВЧ облучения.

Материал и методы. В качестве экспериментального материала и объекта исследований нами были выбраны белые крысы популяции Вистар обоих полов массой 190-250 2, содержание, уход и методы экспериментальной работы с животными соответствовали общепринятым нормам (И.П. Западнюк, 1983; В.Ф. Москаленко, 2005) и правилам, предусмотренным “Европейской конвенцией по надзору и защите позвоночных животных, которые используются в экспериментальных и других научных иелях" (Страсбург, 1986), Директивой Совета Европейского
Содружества от 24.11.86 г. и распоряжением МЗ Украины № 32 от 22.02.88 г.

Тупая травма грудной клетки у крыс воспроизводилась серией дозированных ударов в область груди разработанным в клинике универсальным устройством для нанесения травм лабораторнымм животным в условиях общего обезболивания кетамином (12,5 мг/100 гмассы тела). Объектом для изучения в эксперименте был прочесс репаративной регенерачии в области дефектов ребер бельх лабораторных крыс. Протокол экспериментов на животных утвержден Комиссией по биоэтике согласно правил Международной конвенции по защите позвоночных животных, используемых в экспериментальных и других научных иелях. Наличие переломов ребер подтверждалось рентгенологически (рис. 1).

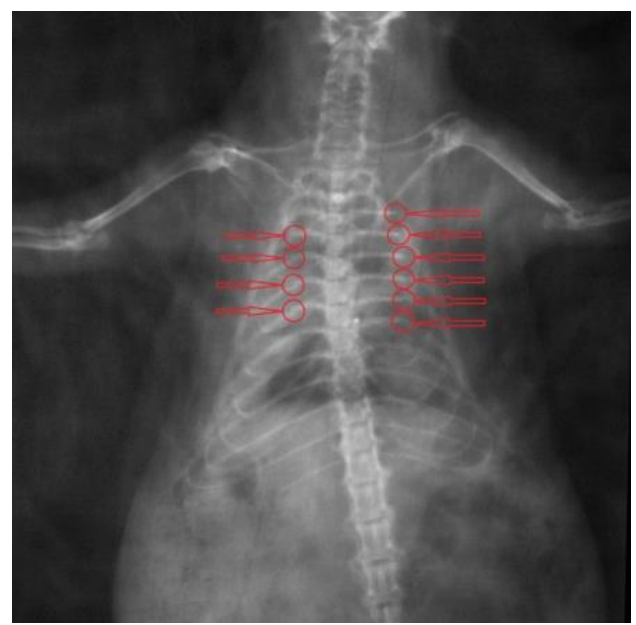

Рис. 1. Множественные переломы ребер у крысы

(C) Исаев М.В. 2015 
Экспериментальные животные были разделены на две группь:: первая (сравнения) - моделирование дефекта проводили у 10 крыс, в посттравматическом периоде умерло 3 животных (летальность 30\%); вторая (основная) - у 10 крыс моделировали тупую травму грудной клетки, в посттравматическом периоде проводили КВЧ облучение области травмы.

Облучение проводили генератором Г4-142, режим излучения непрерывный, выходная мощность 10 мВт, длина волны - 7,1 мм (длина волны избрана на основании анализа данных литературы). В качестве облучателя использовался пирамидальный рупор длиной 90 мм с размерами апертуры $31 \times 24$ мм. Расстояние от плоскости апертуры до поверхности тела животного составляло 15-20 мм. Животным основной группь проводилось по три сеанса КВЧ облучения, длительность сеансов - 20-30 минут. В динамике проводились рентгенологические исследования. Животные выводились из экспериментов на 3, 7, 14, 21, 28 сутки путем передозировки тиопентала-натрия. Реберные кости животных подвергали гистологическому анализу, фиксируя их в формалине, декальиинировали в 5\% растворе азотной кислоты, проводили по спиртам возрастающей концентрачии и заключали в иеллоидин. Срезы (5-7 мкм) окрашивали гематоксилином и эозином, а так же пикрофуксином по Ван-Гизону. Для сравнения площади новообразованной костной ткани (\% от общей площчади дефекта) в дефекте опытных и контрольных животных использован морфометрический метод с применением планиметрической окулярной сетки Автандилова (289 точек).

В поле зрения микроскопа БИОЛАМ (об. 7, ок. 7) подсчитывали число точек, которые приходились на область дефекта и исследуемую ткань в дефекте.

Окрашивание препаратов фукселеном на эластические волокна по Вейгерту с докрашиванием пикрофусином по методу Ван Гизон использовалось для выявления и дифференциачии соединительнотканных структур. Для оценки степени зрелости соединительной ткани препарать окрашивали методом Маллори. Комплекс гистологических и ичитофотометрических исследований проводился на микроскопе Olympus BX-41 c использованием программ Olyтриs DP-Soft (Version 3.1) и Microsoft Excel. Цифровой материал обработан методом вариационной статистики с использованием прикладного пакета STATISTICA6.0 for Windows.
Результаты исследования и обсуждение. На 3 сутки клинически у экспериментальных животных группы сравнения в области травмированных ребер обнаруживали обширный воспалительный инфильтрат, распространяющийся на переднюю грудную стенку. Микроскопически в области дефекта обнаруживали кровяной сгусток с распадающимися эритроцитами и фибрином, в краевых дефектах определяли многочисленные сегментоядерные нейтрофильные гранулоциты с выраженными дегенеративными изменениями (рис. 2).

На 7 сутки эксперимента наблюдения указывали, что у крыс группы сравнения дефекты были выполнены грануляционной тканью из фибробластов, малодифференцированных стромальных клеток и лимфоцитов.

У животных основной группы на 7 сутки эксперимента сохранялись признаки воспаления, однако по краю дефекта определялись единичные грубоволокнистые трабекулы и очаги остеоида (рис. 3).

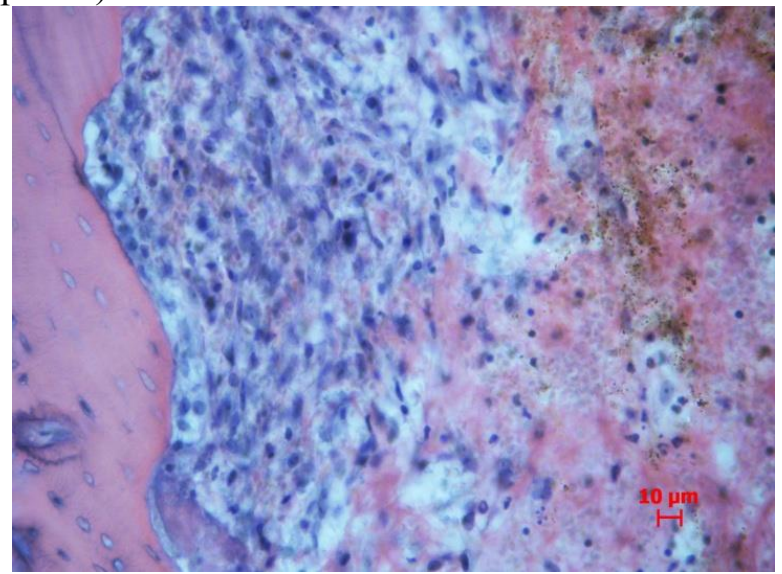

Рис. 2. Животное из группь сравнения, вывод из эксперимента на 3 сутки. Выраженная бактериальная инвазия, в краевых дефектах-многочисленные сегментоядерные нейтрофильные гранулочиты с выраженныли дегенеративными изменениями. Окраска гематоксилином-эозином. Увеличение х200

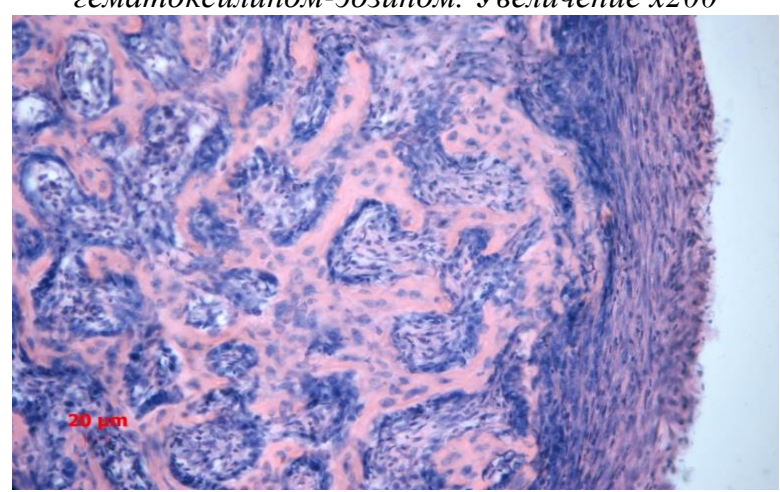

Pис. 3. Животное из основной группь, вывод из эксперимента на 7 сутки. В крае дефекта - единичные грубоволокнистые трабекуль и очаги остеоида.

Окраска гематоксилином-эозином. Увеличение х200 
На 14 сутки у крыс основной группы определяется костная мозоль в виде фибротрабекулярной ткани, материнская кость с большим количеством остеоцитов. Площадь остеоида и новообразованной костной ткани в регенерате животных группы сравнения составляла $15,8 \pm 1,2$ по сравнению с площадью остеоида у животных основной группы $21,2 \pm 1,8(\mathrm{P}<0,05)$.

На 21 сутки у животных группы сравнения остеоид в области дефекта был менее выражен, его площадь составляла $44,8 \pm 2,5$ (P<0,05), то есть в 1,34 раза меньше, чем у животных основной группы $(58,6 \pm 5,1$ при $\mathrm{P}<0.05)$. У животных основной группы на 21 сутки эксперимента отмечено формирование “плотного" регенерата, представленного мелкопетлистой сетью костных незрелых трабекул. В межтрабекулярных пространствах красный костный мозг и небольшие очаги детрита (рис. 4).

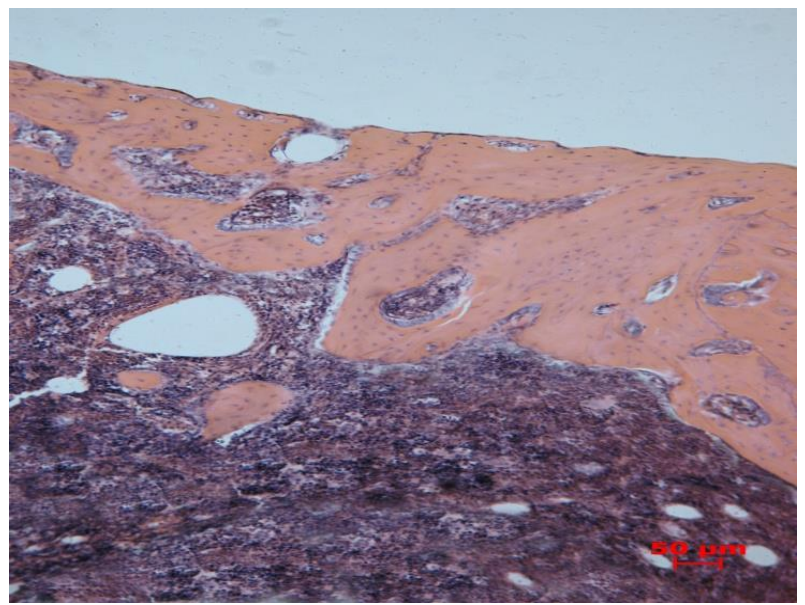

Рис. 4. Животное из основной группь, вывод из эксперимента на 21 сутки. Формирование регенерата. Окраска гематоксилином-эозином. Увеличение 200

На 28 сутки у животных группы сравнения область дефекта была расширена за счет лизиса краевых отделов костной ткани. Регенерат представлен мелкопетлистой сетью костных незрелых трабекул, перемежающихся с небольшими полями фиброретикулярной ткани с высокой плотностью остеобластического дифферона. Следует отметить, что на протяжении всего эксперимента у животных основной группы отмечена более выраженная двигательная активность. На рентгенограммах, выполненных на 7 и 14 сутки эксперимента, отмечено формирование костной мозоли, а на 21 сутки - признаки консолидации перелома (рис. 5).

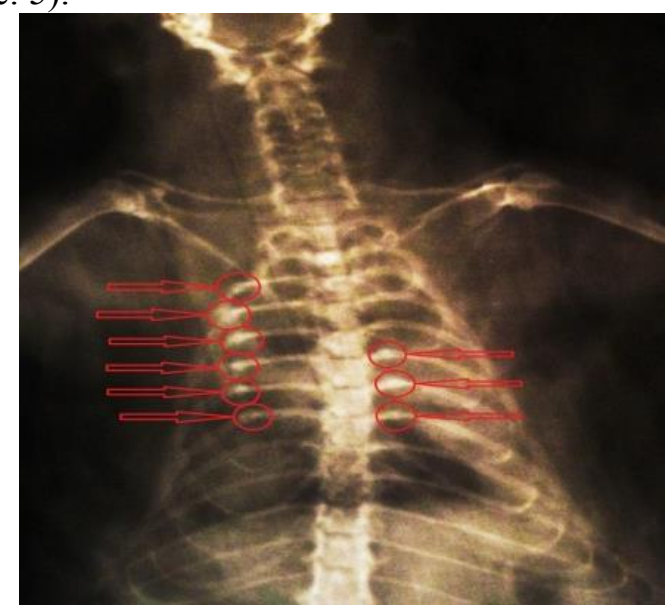

Рис. 5. Формирование костной мозоли, 14 сутки эксперимента

Выводы. 1. Применение КВЧ облучения в посттравматическом периоде у крыс с моделированной тупой травмой грудной клетки приводит к более быстрому формированию костной мозоли (21 сутки эксперимента) по сравнению с животными группы сравнения. 2. Нарушение регенерации у животных группы сравнения возникает на фоне усиленного воспалительного процесса лишь на 14 сутки и в 1,34 раза меньшей площади, нежели у животных основной группы, у которых формирование костной мозоли начиналось уже на 7 сутки исследования. При этом, у животных основной группы отмечено более благоприятное течение посттравматического периода, что обусловлено анальгезирующим эффектом КВЧ излучения. 3. Полученные результаты достоверно указывают на целесообразность включения КВЧ облучения в схему лечения пострадавших с тупой травмой грудной клетки с нарушением костного каркаса.

Перспективы дальнейших исследований. Определить особенности репаративного остеогенеза костей таза под воздействием КВЧ облучения в эксперименте.

\section{Список использованой литературы}

1. Клиника, диагностика и лечение тяжельх повреждений при дорожно-транспортных происшествиях / Под ред. В.Ф. Трубникова. - Харьков: Вища шк., 1980. - 176 с. 2. Королюк А.М. Микробиологические аспекты течения современной посттравматической инфекиии / А.М. Королюк, В.А. Попов, В.Д. Бадилов // Тезисы ХVII съезда Всесоюз. о-ва эпидемиологов, микробиологов и паразитологов. - М., 1989. - Т. 1. - С. 175-176. 3. Запорожан В.Н. Возможности КВЧ-терапии в комплексном лечении доброкачественных и злокачественных опухолей матки / В.Н. Запорожан, М.Б. Голлант, О.В. 
Хаит / Миллиметровые волны нетепловой интенсивности в медицине: сб. международ. симпозиума. - М: ИРЭ АН СССР, 1991. - С. 39-55. 4. Каменев Ю.Ф. Обоснование применения КВЧ излучения для стабилизации дегенеративно-дистрофических изменений в суставном хряще при деформирующем остеоартрозе / Ю.Ф. Каменев, А.М. Герасимов // Миллиметровые волны в биологии и медицине. - 1996. - № 4. - C. 30-34.

\section{ВЛИЯНИЕ КВЧ ОБЛУЧЕНИЯ НА РЕПАРА- ЦИЮ КОСТНОЙ ТКАНИ В ЭКСПЕРИ- MEHTE}

Резюме. В работе представлено экспериментальное обоснование применения КВЧ облучения в раннем посттравматическом периоде при моделированной тупой травме грудной клетки с нарушением целостности реберного каркаса. Использование электромагнитных волн миллиметрового диапазона позволяет снизить выраженность воспалительного процесса, ускорить темпы формирования костной мозоли и способствует формированию плотного регенерата в ранние сроки наблюдения.

Ключевые слова: тупая травма грудной клетки, переломы ребер, КВЧ облучение, эксперимент.

\section{EFFECT OF SWF IRRADIATION ON THE RE- PAIR OF BONE TISSUE IN THE EXPERI- MENT}

Abstract. The work presents an experimental substantiation for the use of SWF irradiation in the early posttraumatic period under simulated blunt chest trauma with damaging of the integrity of the costal frame. The use of electromagnetic millimeter waves can reduce the severity of inflammation, accelerate the pace of callus formation and promotes the formation of dense regenerate in the early period of observation.

Key words: blunt chest trauma, rib fractures, SWF irradiation, experiment.

\author{
Kharkiv National Medical University (Kharkiv) \\ Надійшла 25.03 .2015 p. \\ Рецензент - проф. Польовий В.П. (Чернівці)
}

